\title{
Indoor Air Quality in Chemical Laboratories
}

\author{
T. Ugranli, E. Gungormus, A. Sofuoglu and S.C. Sofuoglu* \\ Izmir Institute of Technology, Izmir, Turkey \\ *Corresponding author: E-mail: cemilsofuoglu@iyte.edu.tr
}

\section{Chapter Outline}

1. Pertinent Pollutants, Sources and Health Effects

1.1 Particulate Matter

1.2 Trace Elements

1.3 Inorganic Gases

1.4 Bioaerosols

1.5 Volatile and Semivolatile

Organic Compounds

2. Factors That Determine the

Concentrations of Indoor Air

Pollutants in Laboratories

2.1 Source Strength

2.2 Ventilation
2.3 Building Characteristics

865

860

860

861

861

862

863

3. Indoor Environmental Comfort 866

3.1 Thermal Comfort $\quad 866$

3.2 Noise 867

3.3 Lighting 867

3.4 Vibration 867

3.5 Odour 868

4. Review of the Literature on Laboratory Indoor Air Quality 868

5. Indoor Environmental Quality

Management

871

864

864

References

875

\section{List of Abbreviations}

ACH Air change per hour

BBP Butyl benzyl phthalate

ChE Chemical Engineering

Department

$\boldsymbol{d}_{\mathbf{p}}$ Particle diameter

DBP Dibutyl phthalate

DEHP Di (2-ethylhexyl) phthalate

DIBP Diisobutyl phthalate

DIDP Diisodecyl phthalate

DINP Diisononyl phthalate

DnOP Di-n-octyl phthalate

DnPP Di-n-pentyl phthalate
HVAC Heating, ventilating and air conditioning

IAQ Indoor air quality

OCP Organochlorine pesticides

PAH Polycyclic aromatic hydrocarbons

PBDE Polybrominated diphenyl ethers

PCB Polychlorinated biphenyls

PCDD Polychlorinated dibenzo- $p$ dioxins

PCDF Polychlorinated dibenzo- $p$ furans

POP Persistent organic pollutants

PVC Polyvinyl chloride 
PM Particulate matter

UFP Ultrafine particles

$\boldsymbol{R}_{\mathbf{a}}$ Minimum outdoor airflow rate required per area

$\boldsymbol{R}_{\mathbf{p}}$ Minimum outdoor airflow rate required per person

RH Relative humidity
SVOC Semivolatile organic

compounds

VOC Volatile organic compounds

WBGT Wet bulb globe temperature

T Temperature

TSP Total suspended solids

TVOC Total volatile organic

compounds

\section{PERTINENT POLLUTANTS, SOURCES AND HEALTH EFFECTS}

Indoor air pollutants important for laboratories can be listed as particulate matter (PM), trace elements, inorganic gases, bioaerosols and volatile organic compounds (VOCs) and semivolatile organic compounds (SVOCs).

\subsection{Particulate Matter}

PM can be regarded as one of the most important and frequently encountered indoor air pollutants. PM is classified into three groups based on their sizes: coarse particles (particles with diameter $2.5<d_{\mathrm{p}} \leq 10 \mu \mathrm{m}$ ), fine particles $\left(0.1<d_{\mathrm{p}} \leq 2.5 \mu \mathrm{m}\right)$ and ultrafine particles (UFP, $\left.d_{\mathrm{p}} \leq 0.1 \mu \mathrm{m}\right)$. Fine particles are more potent when inhaled compared to the coarse fraction because they can penetrate deeper into the respiratory system [1-3]. UFP can penetrate to alveoli, and transfer to blood, which can be considered as the most impacting group [4]. Although the contribution of ultrafine and fine particles are very low and low, respectively, to the PM in mass basis, they have the highest contribution based on the particle number concentration [5].

Possible sources of PM in the laboratories, that determine their concentrations, are combustion sources such as Bunsen burners, used and produced powders in the experiments, human skin scales, insect parts, chipped pieces from walls and other construction materials and generally the main source that is outdoor air. Hence, ventilation plays a major role because it may act as a highway for their transport from outdoors to indoors. Additionally, occupant behaviour in the laboratories can cause resuspension of the settled particles affecting indoor air PM concentrations considerably, along with type of cleaning and its frequency, similar to reports from other indoor microenvironments such as by Abt et al. and Ocak et al. [6,7].

PM is an irritant and a Group-1 carcinogen [8]. The level of toxicity changes depending on the trace element and organic substance content which may be incorporated during the formation of particles and/or sorbed later on from anthropogenic sources. Exposure to PM may lead to effects on respiratory system, such as inflammation, asthma and lung diseases, and 
cardiovascular system such as variability in the heart rate [9-11]. Although health effects of PM have been shown by epidemiological studies, there is not a significant evidence for the effects of particles with different sizes mechanistically [12]. Therefore, the standards set for $\mathrm{PM}_{2.5}$ and $\mathrm{PM}_{10}$ are used to determine the level of health effects.

\subsection{Trace Elements}

Common potentially toxic trace elements associated with $\mathrm{PM}$ are $\mathrm{Al}, \mathrm{Fe}, \mathrm{Mg}$, $\mathrm{Zn}, \mathrm{As}, \mathrm{Cd}, \mathrm{Co}, \mathrm{Cr}, \mathrm{Cu}, \mathrm{Mn}, \mathrm{Ni}$ and $\mathrm{Pb}$. Trace elements such as $\mathrm{Al}, \mathrm{Fe}$ and $\mathrm{Mg}$ are mostly released from the crustal sources like parent rocks, metallic minerals, seas and oceans [13]. Fossil fuel combustion, wood and biomass burning and metal processing can be given as examples of anthropogenic sources releasing many trace elements such as $\mathrm{As}, \mathrm{Cd}, \mathrm{Co}, \mathrm{Cr}, \mathrm{Cu}, \mathrm{Ni}, \mathrm{Pb}$, etc. $[14,15]$. Consequently, ambient air PM-bound trace elements can be carried into the laboratories from outdoors by ventilation and infiltration. In addition, transport on the shoes and clothing of individuals may be a source. Indoor sources may be chipped paint, re-entrainment of the dust settled onto the floors and other horizontal surfaces. However, the main trace element source may be some specific operations and procedures carried out in the laboratories involving processing of solid materials, powders, chemicals, samples, etc., that are rich in trace element content. Chronic exposure to some trace elements may cause various human health effects ranging from irritation of the mucosa and coughing to cardiovascular diseases and cancer [16].

\subsection{Inorganic Gases}

$\mathrm{CO}_{2}$ is one of the minor components of the atmosphere emitted by humans, animals and plants as a result of biological processes. Beside metabolic processes, $\mathrm{CO}_{2}$ is also released to the environment as the major combustion product from vehicles, industries, electricity production and residential heating. Number of workers and students in the laboratory, operation of fume hoods during experiments, presence of combustion sources and ventilation rate are the main factors influencing $\mathrm{CO}_{2}$ levels in laboratories. Types of experiments conducted in the laboratories are also important. For example, if animals and plants are used for different purposes, extra $\mathrm{CO}_{2}$ emissions occur or leakage from the use of $\mathrm{CO}_{2}$ cylinders may occur. If $600 \mathrm{ppm}$ is taken as reference point, decrease in decision-making performance of people was found to be statistically significant at concentrations $>1000 \mathrm{ppm}$, whereas the decrease was more pronounced at concentrations $>2500 \mathrm{ppm}$ [17].

$\mathrm{CO}$ is mainly produced as a result of incomplete combustion in such sources as unvented kerosene heaters and gas appliances [18]. Its indoor concentrations rise above outdoor levels when there are strong indoor sources. Otherwise, ambient air is the main source. $\mathrm{CO}$ gas cylinders are available in 
chemical laboratories and leakages during usage may be a significant source. Additionally, it can also be used as a reducing agent and produced as a result of some chemical reactions (such as reaction of sulphuric acid and formic acid, dehydration of formic acid in the medium of concentrated sulphuric acid, etc.). Exposure to $\mathrm{CO}$ at high levels leads to acute neurological and cardiovascular health effects. $\mathrm{CO}$ exposure may also be a cause of cardiovascular mortality and cardiovascular disease hospitalisation even at the ambient $\mathrm{CO}$ concentrations from 0 to $11 \mathrm{ppm}$ [19].

$\mathrm{NO}$ is formed by reaction of nitrogen and oxygen at high temperatures followed by oxidisation to $\mathrm{NO}_{2} . \mathrm{NO}_{2}$ formation is directly related to heating appliances, tobacco smoke, fireplaces, wood-burning stoves, motor vehicles, industrial boilers and electric utilities [18,20]. Beside the infiltration of outdoor $\mathrm{NO}_{2}$, indoor combustion sources that use LPG and natural gas are the main indoor sources of $\mathrm{NO}_{2}$. In corrosion studies on different surfaces such as zinc, copper and aluminium, $\mathrm{NO}_{2}$ can leak to the indoor air [21]. $\mathrm{NO}_{2}$ is also used as an oxidant for transformation of polycyclic aromatic hydrocarbons (PAHs) to nitro-PAHs [22]. Exposure to $\mathrm{NO}_{2}$ can cause lower respiratory diseases and damages to the lungs [23,24]. Additionally, considerable effects were recorded on the children and asthmatics [25].

$\mathrm{SO}_{2}$ is also considered as one of the important inorganic gases released from combustion processes (kerosene heaters and gas stoves) and industrial sources. Not only gas form of $\mathrm{SO}_{2}$ but also formation of aerosols from $\mathrm{SO}_{2}$ is a big concern in the atmosphere due to acid deposition potential. However, indoor levels are generally found to be lower than those of outdoors [1]. $\mathrm{SO}_{2}$ is used as a reducing agent for bleaching, preservation of foods and disinfection. Respiratory effects, higher pulse rate, nausea and vomiting are possible adverse health effects of $\mathrm{SO}_{2}$ exposure [26-29].

Sources of $\mathrm{O}_{3}$ may be air cleaners, UV lighting, laser printers, photocopiers and photochemical reactions $[20,30] . \mathrm{O}_{3}$ can be used in the organic chemistry laboratories for ozonolysis of compounds, such as eugenol, to obtain carbonyl compounds from alkynes and alkenes, and to investigate air pollution and climate change resulted from stratospheric ozone depletion, while its main source is the outdoor air [31]. Ozone is an important component of indoor air chemistry both consumed and produced depending on other factors including the outdoor $\mathrm{O}_{3}$ concentration, air exchange rates, indoor emission rates, surface removal rates and reactions between $\mathrm{O}_{3}$ and other chemicals in the air [32]. Ozone exposure can lead to headaches; irritation on eyes, nose and throat; difficulty in breathing; increase in the bronchial reactivity and further narrowing of airway for people with asthma [33,34].

\subsection{Bioaerosols}

Bioaerosols are either naturally generated particles or contamination-generated particles from biological origins, and may stay suspended in air because their 
small sizes that can vary from $20 \mathrm{~nm}$ to $>100 \mu \mathrm{m}$ [35]. Beside the organisms (viruses, bacteria and fungi), associated attributes such as spores, toxins, microbial VOCs and antigens are also important to the human health [36].

Indoor air of laboratories can face with the bioaerosol contamination if indoor temperature and relative humidity are suitable for the growth of those organisms. Air conditioners or ventilation systems, outdoor pollution, water baths, ultrasonic baths, sample drying in ovens operating at moderate temperatures $\left(35-40^{\circ} \mathrm{C}\right)$ with moisture content, uncleaned sinks, benches, pumps for water transportation in the laboratory devices, building and furnishing materials, number of people and their activities (sneezing, coughing and talking), organic wastes, water leakages from devices such as climatecontrolled chambers, deionised or ultrapure water systems may be the sources of contamination in chemical laboratories. Exposure to bioaerosols has been related to asthma, humidifier fever, allergic rhinitis, hypersensitivity pneumonitis, pontiac fever, Legionnaire's disease, hypersensitivity pneumonitis and atopic dermatitis $[20,37,38]$.

\subsection{Volatile and Semivolatile Organic Compounds}

VOCs, which are more than 220 compounds, have typically a boiling point range from $50-100^{\circ} \mathrm{C}$ to $240-260^{\circ} \mathrm{C}$, excluding pesticides [39]. These compounds can be classified as aliphatic (methane, hexane, heptane, etc.), aromatic (benzene, toluene, xylene, etc.), oxygenated (aldehydes, alcohols, etc.) and halogenated hydrocarbons (chloroform, methyl chloride, chloromethane, etc.). Hydrocarbons are generally used in the laboratories as solvents (for extraction or purification), cleaning agents for glassware, chemical intermediates for reactions and for instrumental analysis such as the use of ethyl alcohol as mobile phase in chromatography. Leakages from the bottles, spillage while pouring, evaporation from the left open sources, mixing into air from ovens (if solvent containing material is dried) may be the main sources of VOC emissions in the laboratories. Exposure to these pollutants causes adverse health effects such as irritation, impairment of concentration, fatigue, headache and impacts on kidney, lung and nervous system [40-42].

SVOCs are organic compounds with vapour pressures between $10^{-14}$ and $10^{-4} \mathrm{~atm}$, and boiling points from $240-260^{\circ} \mathrm{C}$ to $380-400^{\circ} \mathrm{C}[39,43]$. They can either be in the gas form or adsorbed to available surfaces such as house dust and airborne particles, materials like polyurethane foam, etc. The main groups of SVOCs can be listed as phthalates, polychlorinated biphenyls (PCBs), organochlorine pesticides (OCPs), polychlorinated dibenzo-p-dioxins and-furans (PCDD/PCDFs), PAHs, sulfanates, polybrominated diphenyl ethers (PBDEs) and other brominated flame retardants. Phthalates are used as plasticisers to make products (building materials, polyvinyl chloride (PVC) flooring, toys, cosmetics, etc.) softer and elastic, eg, in PVC [44]. Some of the commercially used phthalates are dibutyl phthalate (DBP), diisobutyl 
phthalate (DIBP), butyl benzyl phthalate (BBP), di-n-pentyl phthalate (DnPP), di (2-ethylhexyl) phthalate (DEHP), di-n-octyl phthalate (DnOP), diisononyl phthalate (DINP) and diisodecyl phthalate (DIDP). Because of having low vapour pressure, they evaporate making the material brittle in time. Phthalates are mostly investigated in chemical laboratories in plastics, toys, foods and cosmetics. Exposure to phthalates can lead to health effects such as impacts on liver, respiratory system and metabolism and development disorders in the reproductive organs [45-48].

SVOCs are categorised as persistent organic pollutants (POPs) because they are resistant to degradation in the environment, can be transported over long distances and bioaccumulate [49]. These compounds are mostly used for industrial or agricultural applications rather than commercially available laboratory products as VOCs. However, some of them, that are currently in use, such as PBDEs and other types of flame retardants, can be emitted from electric/electronic devices and building/furnishing materials. SVOC levels are investigated in different media such as air, soil, water, milk and living organism tissues because they partition between the gaseous phase and organic matter in solid/particle phase. Processing and analysis of samples are carried out in the environmental monitoring laboratories. Depuration chemicals, internal and surrogate standards for instrumental analysis are available in these laboratories. Furthermore, evaporation from the brought in samples is also possible. SVOCs may leak into indoor air of laboratory during extraction, concentration and instrumental analysis of SVOC-containing samples. Possible health effects related to POPs exposure are impacts on immune, endocrine, nervous and reproductive systems; developmental problems; thyroid dysfunction and cancer [50,51].

Finally, building construction materials, caulking, furnishing materials in the laboratory, cleaning products, outdoor air, improper working or not using fume hoods, ventilation rate can be considered as important sources and factors for both VOCs and SVOCs.

\section{FACTORS THAT DETERMINE THE CONCENTRATIONS OF INDOOR AIR POLLUTANTS IN LABORATORIES}

Pollutant source strength and ventilation rate are the two main factors that determine indoor air quality (IAQ) in chemical laboratories. The other factors that may have an effect are building characteristics such as moisture damage, building and furnishing materials, and cleaning products. Indoor air chemistry may also be of importance as a source of secondary pollutants.

\subsection{Source Strength}

One of the main determinants that affect the IAQ is the strength of indoor emissions. The factors that lead to the presence of contaminants in the indoor 
environment are exemplified by indoor sources (combustion sources, construction materials, etc.), outdoor sources, indoor conditions and occupant activities. In other words, source strength depends on the intensity of indoor sources and the factors such as moisture content, temperature, etc. that allow release of pollutants from these types of sources at different rates. For example, the concentrations of volatile organics usually increase linearly with increase in ambient temperature, depending on their volatility properties. Unlike most indoor microenvironments, various types of chemicals are stored in laboratories, and they are used for experiments and analyses. Therefore, exposures to various agents are likely during experiments, and to volatiles during storage in laboratories. People in laboratories can be directly exposed to the chemicals by inhalation and dermal routes, at large quantities making this specific type of indoor microenvironment special to its both types of occupants: staff and students in educational and research laboratories.

\subsection{Ventilation}

Air exchange between outdoor and indoor environments, ie, ventilation, is used to prevent accumulation of pollutants that have strong indoor sources by exchanging indoor and outdoor air, assuming the concentrations are lower in the latter (making it fresh) compared to indoor air. So, ventilation works in two ways: dilution and exhausting. The types of ventilation are classified into two main groups: natural and mechanical ventilation. The air exchange process in natural ventilation depends on the pressure difference associated mainly with air temperature and winds. It occurs by flow of air from the region of higher pressure toward lower pressure, which requires opening the windows to increase the flow. Although it is economical and it has environmental benefits, this method is almost always inadequate for laboratories. Mechanical ventilation is needed because emission strengths and hazardous potencies of laboratory indoor air pollutants are high. HVAC (heating, ventilating and air conditioning) systems are installed to obtain thermal comfort and acceptable IAQ. HVAC systems, operating even at high air change per hour $(\mathrm{ACH})$ values, are generally not sufficient for some experimental procedures with high emission strength. Therefore, fume hoods are also required for exhausting to outdoors directly preventing entrainment into the laboratory air.

\subsection{Building Characteristics}

In addition to ventilation type, the other building characteristics that may affect IAQ in chemical laboratories may be moisture damage, building and furnishing materials, and cleaning products. Moisture damage can occur due to leak or high humidity, and affect building materials and components. The colonisation of building materials and HVAC systems by moulds, bacteria and insect pests is an example that occurs as a result of moisture damage in 
buildings [52]. Building and furnishing materials can emit different types of chemicals (eg, VOCs and SVOCs) which affect IAQ adversely. Cleaning products are another group of emission sources for VOCs. The use of lowemitting products in building, furnishing materials and for cleaning would lead to healthier buildings.

\section{INDOOR ENVIRONMENTAL COMFORT}

Along with IAQ, indoor environmental comfort is the second component of indoor environmental quality. Indoor environmental comfort consists of thermal comfort, noise, lighting, vibration and odours, all of which may affect wellbeing and performance of the occupants. In an environment with lack of comfort, occupants may lose their motivation and may need to make an extra effort not to lose concentration on work [53]. Comfort varies from person to person because of differences in age, gender, nationality, health status, etc.; however, the majority of the occupants should feel comfortable in healthy indoors.

\subsection{Thermal Comfort}

Thermal comfort indicates satisfaction of the occupant from thermal conditions of indoor environment. Therefore, indoor air of laboratories should be neither cooler nor warmer than an optimum temperature range. Thermal comfort is affected from both environmental factors, such as air temperature, relative humidity, air velocity and mean radiant temperature and personal factors (clothing and activity level of people) [54]. Outside air temperature, time of the day and year, heating and cooling capacity of the building, existence of insulation, number of windows and doors and ventilation type are some parameters that can influence the temperature in a laboratory. Oven, muffle furnace, burners, heaters of soxhlet, reactors, separation columns, hotplates and running computers can increase temperature in the laboratories. Changes in the temperature can adversely affect the occupant performance. It was found that $1{ }^{\circ} \mathrm{C}$ increase in temperature decreases the performance in offices by $2 \%$ in the temperature range of $25-32^{\circ} \mathrm{C}$ whereas no observed effect in $21-25^{\circ} \mathrm{C}$ [55]. Additionally, warmer air temperature can lead to unsatisfaction and increased heart rate variation [53]. Comfort ranges are variable according to geographic/climatic regions.

Relative humidity is another important comfort variable that depends on various factors such as temperature, air conditioning, human activities and water content in the laboratory; geographic location of building; existence of humidifiers and experimental conditions. Nasal dryness, nasal congestion and skin dryness can be observed at low humidity conditions [56] whereas mould formation and water damages can occur with elevated humidity because of condensation of excess water on the surfaces. 


\subsection{Noise}

Since chemical laboratories are host to various types of laboratory devices, noise pollution is generally inevitable. Location of the laboratory, noise of outside, poor acoustic design of building, existence of insulation in the windows, air conditioners, fume hoods, compressors, gas generators such as $\mathrm{N}_{2}$, ultrasonic bath and cleaners, stirrers, centrifuge, pumps, refrigerators and most of the other working devices are potential sources of the noise in chemical laboratories. Effect of $2.6 \mathrm{~dB}$ change in noise level was found to be same as $1{ }^{\circ} \mathrm{C}$ change in temperature, and it was shown that the higher the noise level, the higher the thermal unpleasantness [57]. High level and frequency of noise can lead to difficulty in communication. Hearing loss and impairment, cardiovascular diseases, increase in the levels of adrenalin and noradrenalin, headache and nausea are some of the potential health risks of noise pollution [58-62]. Necessary precautions such as insulation, suitable windows and construction materials must be taken for newly constructed buildings. Additionally, equipment minimising noise generation should be chosen if available, for example, the use of lower noise compressors can lower the noise generation by about $10 \mathrm{dBA}$.

\subsection{Lighting}

Lighting is the effective parameter for visual comfort of occupants' wellbeing. It is important in chemical laboratories due to the fact that researchers, laboratory technicians or students spend long hours in these environments, and proper preparation to experiments is very crucial. Colour of lamps, illumination and its uniformity, amount of daylight entering to laboratory, types of lamps (fluorescent light, daylight, etc.) and number of windows determine the quality of lighting of the indoor environment. Low illumination intensity causes decrease in concentration on work while high intensity makes participants feel discomfort [63]. Additionally, insufficient lighting can give rise to decrease in working efficiency, fatigue and nervosity $[64,65]$. Not only light properties but also the incidence direction of the light to the benches (parallel, perpendicular, from one source or more, etc.) affects the workers comfort in a laboratory. The standard for lighting power density of laboratories is $19.5 \mathrm{~W} / \mathrm{m}^{2}$ (converted from $1.81 \mathrm{~W} / \mathrm{ft}^{2}$ ) [66].

\subsection{Vibration}

Sources of vibration in indoor environments can be categorised into two groups as internal and external sources. External sources can be listed as traffic (if building is close to a road or railway), motors of ventilators, winds and building construction, whereas vibration caused by internal sources may be walking of occupants, air conditioners and laboratory equipment such as ultrasonic baths, 
stirrers, fume hoods, centrifuging, pumps, etc. Hand-transmitted vibration contributes to occurrence of hand-arm vibration syndrome, summation of vascular, neurological and musculoskeletal disorders [67]. Furthermore, whole body-transmitted vibration is related to low back pain, sciatic pain and degeneration in spine [68]. Vibration is a problem for the sensitive measurements as in the case of receiving distorted images from a microscope.

\subsection{Odour}

Since chemical laboratories involve a wide diversity of chemicals (acids, VOCs, SVOCs, etc.) or samples for investigation (sludge, wastewater, animal tissues, etc.), odour may be an important issue for the indoor environmental quality. Formation of bioaerosols as a result of water damage and their secretions, furnishing materials and paints (if new building), cleaning products, body odour and most importantly inadequate ventilation are the other sources of odour. Degree of influence of odour varies depending on the intensity, frequency, exposure duration, location and offensiveness [69]. Exposure of chemical workers to odour causes loss of sense of smell, nausea, vomiting, gagging, dizziness, lightheadedness and headaches [69-71].

\section{REVIEW OF THE LITERATURE ON LABORATORY INDOOR AIR QUALITY}

Investigations of IAQ in laboratories have been reported in a very limited number of studies in the international literature [72-76]. These studies are summarised in Table 1 and described in the following paragraphs.

Rumchev et al. [72] conducted a study to assess IAQ in 15 laboratories including five chemistry, six biology, three engineering and computing, and one geology laboratories during the semester and semester break in Curtin University of Technology, Perth, Australia. During sampling periods, laboratories were ventilated naturally or mechanically. After the measurements, a survey was applied to the participants to associate symptoms such as asthma, allergy and fever to the laboratory working hours. The highest median levels of TVOC, UFP, T and RH were measured in chemistry laboratories with the levels of $29.9 \mu \mathrm{g} / \mathrm{m}^{3}$, 21,694 particles $/ \mathrm{cm}^{3}, 23.5^{\circ} \mathrm{C}$ and $52.5 \%$, respectively. $\mathrm{PM}_{10}\left(27 \mu \mathrm{g} / \mathrm{m}^{3}\right.$, engineering laboratory) and $\mathrm{PM}_{2.5}\left(10 \mu \mathrm{g} / \mathrm{m}^{3}\right.$, biology laboratory) levels were slightly higher than those measured in the chemistry laboratory. It was concluded that levels of pollutants and comfort variables were significantly higher in the semester compared to the break. Additionally, $\mathrm{PM}_{10}$, TVOC and T values were higher in the laboratories without an air conditioner. The results of the survey showed that exposure to higher levels of $\mathrm{PM}_{10}$ and TVOC were related to asthma, cough, wheeze, eczema, trouble breathing and itchy eyes.

Valavanidis and Vatista [73] measured IAQ in the undergraduate and research laboratories, lecture halls, classrooms, offices, libraries and cafeterias 


\section{TABLE 1 Summary of Studies About the IAQ of Laboratories in the Literature}

\begin{tabular}{|c|c|c|c|c|c|c|}
\hline Reference & Sampling Location & Sampling Period & $\begin{array}{l}\text { Laboratory } \\
\text { Number and Type }\end{array}$ & $\begin{array}{l}\text { Ventilation } \\
\text { Type }\end{array}$ & $\begin{array}{l}\text { Measured } \\
\text { Variables }\end{array}$ & $\begin{array}{l}\text { Measurement } \\
\text { Location }\end{array}$ \\
\hline $\begin{array}{l}\text { Rumchev } \\
\text { et al. [72] }\end{array}$ & $\begin{array}{l}\text { Curtin University of } \\
\text { Technology, Perth, } \\
\text { Australia }\end{array}$ & $\begin{array}{l}\text { During semester time } \\
\text { and break, } 2002 \text { (using a } \\
4 \text { h period) }\end{array}$ & $\begin{array}{l}\text { Five chemistry, six } \\
\text { biology, three } \\
\text { engineering and } \\
\text { computing, one } \\
\text { geology laboratories }\end{array}$ & $\begin{array}{l}\text { Mechanical (10 } \\
\text { lab) } \\
\text { Natural (5 lab) }\end{array}$ & $\begin{array}{l}\text { VOCs, } \mathrm{PM}_{10}, \mathrm{PM}_{2.5}, \\
\text { UFPs, T and RH }\end{array}$ & Lab indoor air \\
\hline $\begin{array}{l}\text { Valavanidis } \\
\text { and Vatista } \\
{[73]}\end{array}$ & $\begin{array}{l}\text { Chemistry } \\
\text { Department Building } \\
\text { of the University of } \\
\text { Athens, Greece }\end{array}$ & $\begin{array}{l}\text { October-June in } \\
2002-2003, \\
2003-2004 \text { and } \\
2004-2005\end{array}$ & $\begin{array}{l}\text { Undergraduate } \\
\text { experimental and } \\
\text { research laboratories }\end{array}$ & Natural & $\begin{array}{l}\mathrm{CO}_{2}, \mathrm{CO}, \mathrm{NO}_{2}, \mathrm{SO}_{2} \\
\mathrm{O}_{3}, \mathrm{HCHO}, \text { VOCs, } \\
\text { TSP, T, RH, noise and } \\
\text { WBGT }\end{array}$ & Lab indoor air \\
\hline Yau et al. [74] & Malaysia & - & $\begin{array}{l}\text { Four pharmaceutical } \\
\text { laboratories }\end{array}$ & Mechanical & $\begin{array}{l}\mathrm{PM}_{10}, \mathrm{CO}, \mathrm{CO}_{2}, \\
\text { VOCs, } \mathrm{HCHO}, \mathrm{T}, \mathrm{RH} \\
\text { and air velocity }\end{array}$ & Lab indoor air \\
\hline Park et al. [75] & $\begin{array}{l}\text { University Campus } \\
\text { in Seoul, South Korea }\end{array}$ & $\begin{array}{l}\text { Using two } 8 \mathrm{~h} \text { period for } \\
\text { each sampling area }\end{array}$ & $\begin{array}{l}\text { Four laboratory } \\
\text { buildings, two } \\
\text { nonlaboratory } \\
\text { buildings }\end{array}$ & - & VOCs & $\begin{array}{l}\text { At the stacks of } \\
\text { lab fume hoods }\end{array}$ \\
\hline $\begin{array}{l}\text { Ugranli et al. } \\
\text { [76] }\end{array}$ & $\begin{array}{l}\text { Izmir Institute of } \\
\text { Technology, Izmir, } \\
\text { Turkey }\end{array}$ & $\begin{array}{l}\text { Three weekday } \\
\text { measurements with } 8 \mathrm{~h} \\
\text { a day }\end{array}$ & $\begin{array}{l}\text { Three research } \\
\text { laboratories in } \\
\text { chemistry } \\
\text { department and three } \\
\text { in chemical } \\
\text { engineering } \\
\text { department }\end{array}$ & $\begin{array}{l}\text { Mechanical in } \\
\text { chemical } \\
\text { engineering labs } \\
\text { Natural in } \\
\text { chemistry labs }\end{array}$ & $\begin{array}{l}\mathrm{PM}_{2.5}, \mathrm{PM}_{10}, \mathrm{VOC}, \\
\mathrm{CO}_{2}, \mathrm{CO}, \mathrm{T} \text { and } \mathrm{RH}\end{array}$ & Lab indoor air \\
\hline
\end{tabular}


of chemistry department at the University of Athens in Greece for 3 years. Mean levels of $\mathrm{CO}_{2}, \mathrm{CO}, \mathrm{NO}_{2}, \mathrm{SO}_{2}, \mathrm{O}_{3}, \mathrm{HCHO}$, TVOCs and TSP in undergraduate laboratories were $980,3.2,0.3,0.2,0.02,0.025 \mathrm{ppm}, 7.5 \mathrm{mg} / \mathrm{m}^{3}$ and $0.2 \mathrm{mg} / \mathrm{m}^{3}$ for autumn + winter, and $840,2.8,0.3,0.24,0.02,0.32 \mathrm{ppm}$, $8.5 \mathrm{mg} / \mathrm{m}^{3}$ and $0.7 \mathrm{mg} / \mathrm{m}^{3}$ for spring + summer, respectively. These values were found to be 780, 2.6, 0.3, 0.22, $0.02,0.20 \mathrm{ppm}, 6.2 \mathrm{mg} / \mathrm{m}^{3}$ and $0.2 \mathrm{mg} / \mathrm{m}^{3}$ for autumn + winter, and 570, 2.3, 0.24, 0.20, 0.02, $0.25 \mathrm{ppm}, 6.8 \mathrm{mg} / \mathrm{m}^{3}$ and $0.5 \mathrm{mg} / \mathrm{m}^{3}$ for spring + summer in research laboratories. Noise, temperature, and $\mathrm{RH}$ and wet bulb globe temperature in the undergraduate laboratories were in the range of $68-72 \mathrm{~dB}, 16-18^{\circ} \mathrm{C}, 65-70 \%$ and $16-17^{\circ} \mathrm{C}$ for autumn + winter, and $56-69 \mathrm{~dB}, 23-27^{\circ} \mathrm{C}, 48-52 \%$ and $18-19^{\circ} \mathrm{C}$ for spring + summer, respectively, while those were measured as $55-66 \mathrm{~dB}$, $15-18^{\circ} \mathrm{C}, 65-72 \%$ and $16-17^{\circ} \mathrm{C}$ for autumn + winter, and $54-67 \mathrm{~dB}$, $24-26^{\circ} \mathrm{C}, 45-50 \%$ and $18-20^{\circ} \mathrm{C}$ for spring and summer in research laboratories, respectively. High number of students leads to $\mathrm{CO}_{2}$ concentrations $>1000$ ppm in the undergraduate laboratories. Concentrations of $\mathrm{NO}_{2}$ and $\mathrm{SO}_{2}$ were not considerable and not associated to the experimental studies and number of people. Measured $\mathrm{O}_{3}$ levels were similar to those measured outdoors. Elevated levels of TVOC and $\mathrm{HCHO}$ in the laboratories were related to volatilisation from sources and applied experimental procedures. It was concluded that higher temperatures led to higher volatilisation rates from solvents, thus more contamination in summer. It was found that concentrations of $\mathrm{CO}_{2}, \mathrm{CO}$ and TSP were highly affected from ventilation because natural ventilation was restricted in winter.

Comfort variables and indoor air pollutants in pharmaceutical laboratories were studied in Malaysia [74]. Air temperature and RH in the laboratories were ranged $19.5-23.0^{\circ} \mathrm{C}$ and $49.1-63.5 \%$, respectively. Temperature and $\mathrm{RH}$ values were below the standard of ASHRAE except for one laboratory. It was claimed that cooling level of air conditioner in the laboratories could be decreased for satisfactory thermal conditions. Average concentrations of $\mathrm{PM}_{10}$, $\mathrm{CO}, \mathrm{CO}_{2}$, TVOC and $\mathrm{HCHO}$ were in the range of $2310-5390$ particles $/ \mathrm{m}^{3}$, $0.73-2.5,475-511,0.5-2.6$ and $0.0323-0.0465 \mathrm{ppm}$, respectively. $\mathrm{PM}_{0.1}$, $\mathrm{PM}_{0.5}, \mathrm{PM}_{1}, \mathrm{PM}_{3}$ and $\mathrm{PM}_{5}$ were also measured in the study. Except for TVOC concentrations in two microenvironments (chemical and washing rooms), pollutants were not exceeding the standards, so it was recommended that ventilation rate in those laboratories should be increased.

Park et al. [75] investigated VOC concentrations at the stacks of laboratory fume hoods in a university campus in Seoul, South Korea. Building average $\Sigma_{11}$ VOC concentrations were significantly higher in the four laboratory buildings (range: $85-393 \mu \mathrm{g} / \mathrm{m}^{3}$ ) than the two nonlaboratory buildings with values of 9.30 and $18.32 \mu \mathrm{g} / \mathrm{m}^{3}$ due to utilisation of large amount of chemicals and improperly working purification systems. The differences among the laboratory buildings were considered as the indication of effects caused by experimental conditions. 
IAQ and environmental comfort variables were investigated by Ugranli et al. [76] in research laboratories of Departments of Chemistry and Chemical Engineering at Izmir Institute of Technology in Izmir, Turkey. Average values of measured parameters, $\mathrm{PM}_{2.5}, \mathrm{PM}_{10}$, TVOC, $\mathrm{CO}_{2}, \mathrm{CO}, \mathrm{T}$ and $\mathrm{RH}$, were in the range of $9.30-26.2 \mu \mathrm{g} / \mathrm{m}^{3}, 26.1-63.0 \mu \mathrm{g} / \mathrm{m}^{3}, 33.3-43.1 \mathrm{ppb}, 413-514 \mathrm{ppm}$, below detection limit, $23.0-25.0^{\circ} \mathrm{C}$ and $35.3-44.8 \%$, respectively, in the laboratories of chemistry department. The respective concentrations were measured as $7.64-19.4 \mu \mathrm{g} / \mathrm{m}^{3}, \quad 12.5-48.3 \mu \mathrm{g} / \mathrm{m}^{3}, \quad 13.8-182 \mathrm{ppb}, \quad 0.08-$ $0.99 \mathrm{ppm}, 402-413 \mathrm{ppm}, 26.0-30.0^{\circ} \mathrm{C}$ and $39.0-46.0 \%$ in the laboratories of the Department of Chemical Engineering (ChE). Levels of $\mathrm{PM}_{2.5}$ and $\mathrm{PM}_{10}$ were found to be related to occupant behaviour, number of people in the laboratory, and outdoor sources thus ventilation. In general, pollutant concentrations and comfort variables were in compliance with the standards (except for TVOC and temperature in one laboratory), hence ventilation systems were sufficient to keep indoor air healthy and comfortable. Therefore, it was recommended to install air conditioner to keep temperature values in the comfort zone. Descriptive statistics for the measured variables reported in the five studies are summarised in Table 2.

The project, in which the study by Ugranli et al. was a part of, also included investigation of the indoor environmental comfort of laboratory staff in ChE [77]. All 19 research laboratories in ChE were visited for observation/assessment of risk factors regarding safety and hygiene. Almost all of the staff of the 19 laboratories $(90.2 \%, n=38)$ were administered a questionnaire regarding their use of/exposure to physical, chemical, biological and ergonomic risk factors. The observations and the occupant responses were classified according to a four-level scheme. The staff of $\mathrm{ChE}$ research laboratories who participated in the study was consisted of 29 females $(76 \%)$ and 9 males $(24 \%)$ who were research assistants, specialists and technicians. Majority (79\%) of the laboratories had records of the chemicals used while the remaining had partial records. Majority of the laboratories were found to be not satisfactory by the occupants in terms of ventilation and thermal comfort (Table 3). The highest uses of chemicals, therefore probable exposures, were of inorganic gases $(80 \%)$ and the least to metals (58\%). Preventive measures regarding the use of chemicals were in place in all laboratories; however, they were considered as not sufficient by the occupants against direct exposure to solvents and acids in $48 \%$ of the laboratories (Table 3 ). The majority of the laboratories were classified as sufficient in terms of cleanliness and tidiness (\%53); however, the majority were classified as not sufficient $(21 \%)$ or somewhat sufficient $(47 \%)$ regarding compliance to the university's laboratory safety and hygiene rules.

\section{INDOOR ENVIRONMENTAL QUALITY MANAGEMENT}

IAQ and occupational safety guidelines/standards can be used to evaluate laboratories, in order to consider management measures to obtain acceptable 
TABLE 2 Descriptive Statistics [Mean/Median (Range)] of Indoor Air Quality and Environmental Comfort Variables Measured in Laboratories

\begin{tabular}{|c|c|c|c|c|c|c|c|c|c|c|c|c|c|c|c|c|c|c|c|}
\hline & \multicolumn{3}{|c|}{ Rumchev et al. [72] } & \multicolumn{4}{|c|}{ Valavanidis and Vatista [73] } & \multicolumn{4}{|c|}{ Yau et al. [74] } & \multicolumn{2}{|c|}{ Park et al. [75] } & \multicolumn{6}{|c|}{ Ugranli et al. [76] } \\
\hline & \multirow{2}{*}{$\begin{array}{l}\text { Chemistry } \\
\text { Labs }\end{array}$} & \multirow{2}{*}{$\begin{array}{l}\text { Biology } \\
\text { Labs }\end{array}$} & \multirow{2}{*}{ Eng. Labs } & \multicolumn{2}{|c|}{ Undergraduate Labs } & \multicolumn{2}{|c|}{ Research Labs } & \multirow{2}{*}{ Lab. 1} & \multirow{2}{*}{ Lab. 2} & \multirow{2}{*}{ Lab. 3} & \multirow{2}{*}{ Lab. 4} & \multirow{2}{*}{$\begin{array}{l}\text { Lab. } \\
\text { Buildings }\end{array}$} & \multirow{2}{*}{$\begin{array}{l}\text { Non-lab. } \\
\text { Buildings }\end{array}$} & \multicolumn{3}{|c|}{ Chemistry Department } & \multicolumn{3}{|c|}{ Chemical Engineering Department } \\
\hline & & & & $\begin{array}{l}\text { wintert } \\
\text { autumn }\end{array}$ & $\begin{array}{l}\text { spring+ } \\
\text { summer }\end{array}$ & $\begin{array}{l}\text { wintert } \\
\text { autumn }\end{array}$ & $\begin{array}{l}\text { spring+ } \\
\text { summer }\end{array}$ & & & & & & & Lab. 1 & Lab. 2 & Lab. 3 & Lab. 1 & Lab. 2 & Lab. 3 \\
\hline \multicolumn{20}{|c|}{ Concentrations of Pollutants } \\
\hline TVOC & $\begin{array}{l}-/ 29.9 \\
(3.4-83.4) \\
\mu g / \mathrm{m}^{3}\end{array}$ & $\begin{array}{l}-/ 22.3 \\
(6.3-85.1) \\
\mu g / \mathrm{m}^{3}\end{array}$ & $\begin{array}{l}-/ 13.9 \\
(12.7-31.3) \\
\mu \mathrm{g} / \mathrm{m}^{3}\end{array}$ & $\begin{array}{l}7.5 /- \\
(3.0-7.0) \\
\mathrm{mg} / \mathrm{m}^{3}\end{array}$ & $\begin{array}{l}8.5 /- \\
(6.8-9.5) \\
m g / \mathrm{m}^{3}\end{array}$ & $\begin{array}{l}6.2 /- \\
(4.2-6.7) \\
\mathrm{mg} / \mathrm{m}^{3}\end{array}$ & $\begin{array}{l}6.8 /- \\
(4.5-7.8) \\
\mathrm{mg} / \mathrm{m}^{3}\end{array}$ & $\begin{array}{l}2.6 /- \\
\mathrm{ppm}\end{array}$ & $\begin{array}{l}1.3 /- \\
\mathrm{ppm}\end{array}$ & $\begin{array}{l}3.5 /- \\
\mathrm{ppm}\end{array}$ & $\begin{array}{l}0.5 /- \\
\mathrm{ppm}\end{array}$ & $\begin{array}{l}184.74^{*} /- \\
\mu \mathrm{g} / \mathrm{m}^{3}\end{array}$ & $\begin{array}{l}12.1 \% \% \\
\mu \mathrm{g} / \mathrm{m}^{3}\end{array}$ & $\begin{array}{l}33.3 / 22.6 \\
(0.00-78.3) \\
\text { ppb }\end{array}$ & $\begin{array}{l}34.5 / 29.8 \\
(0.00-82.2) \\
\text { ppb }\end{array}$ & $\begin{array}{l}33.1 / 24.5 \\
(0-938) \\
\mathrm{ppb}\end{array}$ & $\begin{array}{l}13.8 / 14.1 \\
(2.80-63.5) \\
\text { ppb }\end{array}$ & $\begin{array}{l}20.3-13.8 \\
(6.40-76.6) \\
\text { ppb }\end{array}$ & $\begin{array}{l}182-103 \\
(3.70-2379) \\
\mathrm{ppb}\end{array}$ \\
\hline $\mathrm{PM}_{25}$ & $\begin{array}{l}-79.00 \\
(4.2-25.1) \\
\mu \mathrm{g} / \mathrm{m}^{3}\end{array}$ & $\begin{array}{l}-/ 10.0 \\
(5.2-43.3) \\
\mu g / \mathrm{m}^{3}\end{array}$ & $\begin{array}{l}-1 / 8.1 \\
(4.1 \cdot 14.2) \\
\mu \mathrm{g} / \mathrm{m}^{3}\end{array}$ & & & & & & & & & & & $\begin{array}{l}9.30 / 9.56 \\
(5.31-13.0) \\
\mu g / \mathrm{m}^{3}\end{array}$ & $\begin{array}{l}18.7 / 18.3 \\
(17.6-20.2) \\
\mu \mathrm{g} / \mathrm{m}^{3}\end{array}$ & $\begin{array}{l}26.22 / 23.8 \\
(16.8-38.1) \\
\mu g / m^{3}\end{array}$ & $\begin{array}{l}7.64 / 4.17 \\
(1.04-17.7) \\
\mu g / \mathrm{m}^{3}\end{array}$ & $\begin{array}{l}10.4 / 9.38 \\
(6.30-15.6) \\
\mu \mathrm{g} / \mathrm{m}^{3}\end{array}$ & $\begin{array}{l}19.4 / 17.7 \\
(15.6-25.0) \\
\mu \mathrm{gg} / \mathrm{m}^{3}\end{array}$ \\
\hline $\mathrm{PM}_{10}$ & $\begin{array}{l}-/ 17.0 \\
(8.2-46.1) \\
\mu \mathrm{g} / \mathrm{m}^{3}\end{array}$ & $\begin{array}{l}-/ 19.5 \\
(13.1-47.3) \\
\mu \mathrm{g} / \mathrm{m}^{3}\end{array}$ & $\begin{array}{l}-/ 27.0 \\
(10.1-29.2) \\
\mu \mathrm{g} / \mathrm{m}^{3}\end{array}$ & & & & & $\begin{array}{l}3860 /- \\
(0-10600) \\
\text { particle/m }\end{array}$ & $\begin{array}{l}5390 /- \\
(0-15200) \\
\text { particle/m }\end{array}$ & $\begin{array}{l}4020 /- \\
(0-10600) \\
\text { particle } / \mathrm{m}^{3}\end{array}$ & $\begin{array}{l}2310 /- \\
(0-10500) \\
\text { particle/m }\end{array}$ & & & $\begin{array}{l}30.6 / 31.2 \\
(8.70-79.5) \\
\mu \mathrm{g} / \mathrm{m}^{3}\end{array}$ & $\begin{array}{l}26.1 / 30.4 \\
(5.00-62.4) \\
\mu \mathrm{g} / \mathrm{m}^{3}\end{array}$ & $\begin{array}{l}63.0 / 41.8 \\
(14.6-328) \\
\mu \mathrm{g} / \mathrm{m}^{3}\end{array}$ & $\begin{array}{l}12.5 / 9.43 \\
(2.35-39.0) \\
\mu \mathrm{g} / \mathrm{m}^{3}\end{array}$ & $\begin{array}{l}14.4 / 14.6 \\
(1.35-47.1) \\
\mu g / m^{3}\end{array}$ & $\begin{array}{l}48.3 / 322.2 \\
(6.10-206) \\
\mu g / \mathrm{m}^{3}\end{array}$ \\
\hline UFP & $\begin{array}{l}-/ 21694.5 \\
(6029.2- \\
33998.1) \\
\left(\mathrm{n} / \mathrm{cm}^{3}\right)\end{array}$ & $\begin{array}{l}-/ 5637 \\
(5485.1- \\
21740.2) \\
\left(\mathrm{n} / \mathrm{cm}^{3}\right)\end{array}$ & $\begin{array}{l}-19245 \\
(5634.1- \\
12019.2 \\
\left(\mathrm{n} / \mathrm{cm}^{3}\right)\end{array}$ & & & & & & & & & & & & & & & & \\
\hline TSP & & & & $\begin{array}{l}0.2 /- \\
(0.10-0.30) \\
m \mathrm{gg} / \mathrm{m}^{3}\end{array}$ & $\begin{array}{l}0.7 /- \\
(0.4-0.80) \\
\mathrm{mg} / \mathrm{m}^{3}\end{array}$ & $\begin{array}{l}0.2 /- \\
(0.10-0.30) \\
\mathrm{mg} / \mathrm{m}^{3}\end{array}$ & $\begin{array}{l}0.5 /- \\
(0.25-0.70) \\
\mathrm{mg} / \mathrm{m}^{3}\end{array}$ & & & & & & & & & & & & \\
\hline $\mathrm{CO}_{2}$ & & & & $\begin{array}{l}980 /- \\
\text { (770-11000) } \\
\text { ppm }\end{array}$ & $\begin{array}{l}840 /- \\
(700-870) \\
\text { ppm }\end{array}$ & $\begin{array}{l}780 /- \\
(450-850) \\
\text { ppm }\end{array}$ & $\begin{array}{l}570 /- \\
(460-640) \\
\text { ppm }\end{array}$ & $\begin{array}{l}\text { 504.11/- } \\
\text { ppm }\end{array}$ & $\begin{array}{l}511.35 /- \\
\text { ppm }\end{array}$ & $\begin{array}{l}\text { 475.15/- } \\
\text { ppm }\end{array}$ & $\begin{array}{l}488.41 /- \\
\mathrm{ppm}\end{array}$ & & & $\begin{array}{l}14 / 503 \\
(401-725) \\
\mathrm{ppm}\end{array}$ & $\begin{array}{l}663 / 462 \\
(409-544) \\
\mathrm{ppm}\end{array}$ & $\begin{array}{l}13 / 415 \\
(364-471) \\
\mathrm{ppm}\end{array}$ & $\begin{array}{l}13 / 398 \\
(356-608) \\
\mathrm{ppm}\end{array}$ & $\begin{array}{l}402 / 406 \\
(316-622) \\
\mathrm{ppm}\end{array}$ & $\begin{array}{l}410 / 411 \\
(343-536) \\
\mathrm{ppm}\end{array}$ \\
\hline co & & & & $\begin{array}{l}3.2 /- \\
(2.3-4.4) \\
\text { ppm }\end{array}$ & $\begin{array}{l}2.8 /- \\
(2.2-3.1) \\
\text { ppm }\end{array}$ & $\begin{array}{l}2.6 /- \\
(2.1-3.3) \\
\mathrm{ppm}\end{array}$ & $\begin{array}{l}2.3 / . \\
(1.8-2.7) \\
\text { ppm }\end{array}$ & $\begin{array}{l}2.5 /- \\
\mathrm{ppm}\end{array}$ & $\begin{array}{l}0.9 /- \\
\mathrm{ppm}\end{array}$ & $\begin{array}{l}1.5 /- \\
\mathrm{ppm}\end{array}$ & $\begin{array}{l}0.73 /- \\
\mathrm{ppm}\end{array}$ & & & & & & $\begin{array}{l}0.99 / 1.00 \\
(0.60-1.05) \\
\mathrm{ppm}\end{array}$ & $\begin{array}{l}0.65 / 0.95 \\
(0.00-1.95) \\
\mathrm{ppm}\end{array}$ & $\begin{array}{l}0.08 / 0.00 \\
(0.00-1.00) \\
\text { ppm }\end{array}$ \\
\hline $\mathrm{NO}_{2}$ & & & & $\begin{array}{l}0.3 /- \\
(0.30-0.32) \\
\mathrm{ppm}\end{array}$ & $\begin{array}{l}0.3 /- \\
(0.20-0.30) \\
\mathrm{ppm}\end{array}$ & $\begin{array}{l}0.3 /- \\
(0.12-0.30) \\
\mathrm{ppm}\end{array}$ & $\begin{array}{l}0.24 /- \\
(0.20-0.28) \\
\text { ppm }\end{array}$ & & & & & & & & & & & & \\
\hline $\mathrm{SO}_{2}$ & & & & $\begin{array}{l}0.2 /- \\
(0.18-0.20) \\
\mathrm{ppm}\end{array}$ & $\begin{array}{l}0.24 /- \\
(0.20-0.30) \\
\mathrm{ppm}\end{array}$ & $\begin{array}{l}0.22 /- \\
(0.20-0.25) \\
\mathrm{ppm}\end{array}$ & $\begin{array}{l}0.20 /- \\
(0.18-0.20) \\
\text { ppm }\end{array}$ & & & & & & & & & & & & \\
\hline $\mathrm{O}_{3}$ & & & & $\begin{array}{l}0.02 /- \\
(0.01-0.02) \\
\text { ppm }\end{array}$ & $\begin{array}{l}0.02 /- \\
(0.01-0.03) \\
\mathrm{ppm}\end{array}$ & $\begin{array}{l}0.02 /- \\
(0.01-0.28) \\
\text { ppm }\end{array}$ & $\begin{array}{l}0.02 /- \\
(0.02-0.1) \\
\text { ppm }\end{array}$ & & & & & & & & & & & & \\
\hline $\begin{array}{l}\mathrm{HCHO} \\
(\mathrm{ppm})\end{array}$ & & & & $\begin{array}{l}0.025 /- \\
(0.20-0.28) \\
\text { ppm }\end{array}$ & $\begin{array}{l}0.32 /- \\
(0.20-0.45) \\
\text { ppm }\end{array}$ & $\begin{array}{l}0.20 /- \\
(0.10-0.25) \\
\text { ppm }\end{array}$ & $\begin{array}{l}0.25 /- \\
(0.10-0.30) \\
\text { ppm }\end{array}$ & $\begin{array}{l}0.0465 /- \\
\mathrm{ppm}\end{array}$ & $\begin{array}{l}0.0428 /- \\
\mathrm{ppm}\end{array}$ & $\begin{array}{l}\text { 0.0323/- } \\
\text { ppm }\end{array}$ & $\begin{array}{l}0.0386 /- \\
\text { ppm }\end{array}$ & & & & & & & & \\
\hline $\begin{array}{l}\text { Settled } \\
\text { Dust }\end{array}$ & & & & $\begin{array}{l}-/- \\
(360-450) \\
\mathrm{mg} / \mathrm{m}^{2}\end{array}$ & $\begin{array}{l}-/- \\
(400-480) \\
\mathrm{m} / \mathrm{m}^{2}\end{array}$ & $\begin{array}{l}-/- \\
(350-400) \\
\mathrm{mg} / \mathrm{m}^{2}\end{array}$ & $\begin{array}{l}-/- \\
(340-380) \\
\mathrm{mg} / \mathrm{m}^{2}\end{array}$ & & & & & & & & & & & & \\
\hline \multicolumn{20}{|c|}{ Physical Measurements } \\
\hline $\mathrm{T}\left(\mathrm{P}^{\circ} \mathrm{C}\right)$ & $\begin{array}{l}-/ 23.5 \\
(20.0-29.1)\end{array}$ & $\begin{array}{l}-/ 23.1 \\
(21.5-26)\end{array}$ & $\begin{array}{l}-/ 23.1 \\
(22.8-26.1)\end{array}$ & $\begin{array}{l}- \\
(16-18)\end{array}$ & $\begin{array}{l}-/ \\
(23-27)\end{array}$ & $\begin{array}{l}- \\
(15-18)\end{array}$ & $\begin{array}{l}- \\
(24-26)\end{array}$ & $22.38 /-$ & $22.97 /-$ & $20.53 /-$ & $19.50 /-$ & & & $\begin{array}{l}23.0 / 22.9 \\
(21.5-24.6)\end{array}$ & $\begin{array}{l}23.8 / 25.2 \\
(22.8-26.3)\end{array}$ & $\begin{array}{l}25.0 / 25.2 \\
(22.7-27.1)\end{array}$ & $\begin{array}{l}28.0 / 28.0 \\
(24.0-30.0)\end{array}$ & $\begin{array}{l}30.0 / 30.0 \\
(27.0-32.0)\end{array}$ & $\begin{array}{l}26.0 / 26.0 \\
(21.0-28.0)\end{array}$ \\
\hline RH (\%) & $\begin{array}{l}-/ 52.5 \\
(41.0-75.1)\end{array}$ & $\begin{array}{l}-/ 44.1 \\
(32.5-52,1)\end{array}$ & $\begin{array}{l}-/ 45.9 \\
(37.3-53.3)\end{array}$ & $\begin{array}{l}-/ \\
(65-70)\end{array}$ & $\begin{array}{l}- \\
(48-52)\end{array}$ & $\begin{array}{l}-1- \\
(65-72)\end{array}$ & $\begin{array}{l}-\% \\
(45-50)\end{array}$ & $50.76 /-$ & $49.10 /-$ & $59.92 /-$ & $63.50 /-$ & & & $\begin{array}{l}35.3 / 355.6 \\
(34.1-46.1)\end{array}$ & $\begin{array}{l}39.1 / 40.4 \\
(36.0-46.1)\end{array}$ & $\begin{array}{l}44.8 / 45.6 \\
(37.7-51.5)\end{array}$ & $\begin{array}{l}40.0 / 40.0 \\
(37.0-47.0)\end{array}$ & $\begin{array}{l}39.0 / 39.0 \\
(30.0-49.0)\end{array}$ & $\begin{array}{l}46.0 / 48.0 \\
(35.0-53.0)\end{array}$ \\
\hline $\begin{array}{l}\text { Noise } \\
\text { (dB) }\end{array}$ & & & & $\begin{array}{l}-/ \\
(68-72)\end{array}$ & $\begin{array}{l}-- \\
(56-69)\end{array}$ & $\begin{array}{l}-/ \\
(55-66)\end{array}$ & $\begin{array}{l}-/ \\
(54-67)\end{array}$ & & & & & & & & & & & & \\
\hline $\begin{array}{l}\text { WBGT } \\
\left({ }^{\circ} \mathrm{C}\right)\end{array}$ & & & & $\begin{array}{l}-/ \\
(16-17)\end{array}$ & $\begin{array}{l}-\% \\
(18-19)\end{array}$ & $\begin{array}{l}-\mu \\
(16-17)\end{array}$ & $\begin{array}{l}-\angle \\
(18-20)\end{array}$ & & & & & & & & & & & & \\
\hline $\begin{array}{l}\text { Air } \\
\text { Velocity } \\
(\mathrm{m} / \mathrm{s})\end{array}$ & & & & & & & & $\begin{array}{l}0.16 /- \\
(0.08-0.23)\end{array}$ & $\begin{array}{l}0.08 /- \\
(0.08 / 0.11)\end{array}$ & $\begin{array}{l}0.09 /- \\
(0.03-0.16)\end{array}$ & $\begin{array}{l}0.09 /- \\
(0.03-0.19)\end{array}$ & & & & & & & & \\
\hline
\end{tabular}

TVOC, Total volatile organic compounds; $P M$, particulate matter; UFPS, ultrafine particles; $T S P$, total suspended particles; $R H$, relative humidity; WBGT, wet bulb globe temperature.

${ }^{*}$ geometric mean 
TABLE 3 Physical and Chemical Risk Factors Assessed by Staff in ChE Laboratories (\%)

\begin{tabular}{|c|c|c|c|c|c|}
\hline \multicolumn{2}{|l|}{ Physical } & Absolutely Sufficient & Sufficient & Not Sufficient & Absolutely Not Sufficient \\
\hline \multicolumn{2}{|l|}{ Ventilation } & 0.00 & 10.5 & 68.4 & 21.1 \\
\hline \multicolumn{2}{|c|}{ Thermal comfort } & 15.8 & 10.5 & 73.7 & 0.00 \\
\hline \multicolumn{2}{|l|}{ Noise } & 36.8 & 15.8 & 36.8 & 15.8 \\
\hline Chemical & $\begin{array}{l}\text { No } \\
\text { Danger }\end{array}$ & $\begin{array}{l}\text { Danger-Sufficient Preventive } \\
\text { Measures }\end{array}$ & \multicolumn{2}{|c|}{$\begin{array}{l}\text { Danger-not Sufficient Preventive } \\
\text { Measures }\end{array}$} & $\begin{array}{l}\text { Danger-no Preventive } \\
\text { Measures }\end{array}$ \\
\hline Metals & 57.9 & 26.3 & \multicolumn{2}{|l|}{15.8} & 0.0 \\
\hline Solvents & 15.8 & 36.8 & \multicolumn{2}{|l|}{47.4} & 0.0 \\
\hline Acids-bases & 15.8 & 36.8 & \multicolumn{2}{|l|}{47.4} & 0.0 \\
\hline Gases & 20.0 & 68.0 & \multicolumn{2}{|l|}{12.0} & 0.0 \\
\hline
\end{tabular}




\section{TABLE 4 Indoor Environmental Quality/Occupational Safety Standards}

\begin{tabular}{|c|c|c|c|}
\hline Indoor Environmental Factor & Limit & AT & Reference \\
\hline \multirow[t]{3}{*}{$\mathrm{PM}_{2.5}\left(\mu \mathrm{g} / \mathrm{m}^{3}\right)$} & \multicolumn{3}{|c|}{ Indoor air } \\
\hline & 35 & $24 \mathrm{~h}$ & USEPA [81] \\
\hline & 100 & $1 \mathrm{~h}$ & Health Canada [82] \\
\hline \multirow[t]{2}{*}{$\mathrm{PM}_{10}\left(\mu \mathrm{g} / \mathrm{m}^{3}\right)$} & \multicolumn{3}{|l|}{ Indoor air } \\
\hline & 150 & $24 \mathrm{~h}$ & USEPA [81] \\
\hline \multirow[t]{2}{*}{ TVOC $\left(\mu \mathrm{g} / \mathrm{m}^{3}\right)$} & \multicolumn{3}{|c|}{ Indoor air } \\
\hline & 300 & $8 \mathrm{~h}$ & Seifert et al. [87] \\
\hline \multirow[t]{7}{*}{$\mathrm{NO}_{2}$ (ppm) } & \multicolumn{3}{|c|}{ Indoor air } \\
\hline & 0.053 & 1 year & USEPA [81] \\
\hline & 0.25 & $1 \mathrm{~h}$ & Health Canada [82] \\
\hline & 0.02 & 1 year & \multirow[t]{2}{*}{ WHO [83] } \\
\hline & 0.11 & $1 \mathrm{~h}$ & \\
\hline & \multicolumn{3}{|c|}{ Occupational } \\
\hline & 5 & $8 \mathrm{~h}$ & MAK [84] \\
\hline \multirow[t]{6}{*}{$\mathrm{CO}(\mathrm{ppm})$} & \multicolumn{3}{|c|}{ Indoor air } \\
\hline & 9 & $8 \mathrm{~h}$ & USEPA [81] \\
\hline & 11 & $8 \mathrm{~h}$ & Health Canada [82] \\
\hline & 8.7 & $8 \mathrm{~h}$ & WHO [83] \\
\hline & \multicolumn{3}{|c|}{ Occupational } \\
\hline & 30 & $8 \mathrm{~h}$ & MAK [84] \\
\hline \multirow[t]{3}{*}{$\mathrm{CO}_{2}(\mathrm{ppm})$} & \multicolumn{3}{|c|}{ Occupational } \\
\hline & 5000 & $8 \mathrm{~h}$ & NIOSH [85] \\
\hline & 10000 & $1 \mathrm{~h}$ & MAK [84] \\
\hline \multirow[t]{6}{*}{$\mathrm{T}\left({ }^{\circ} \mathrm{C}\right)$} & \multicolumn{3}{|l|}{ Indoor air } \\
\hline & $23.5-28$ & Summer & \multirow[t]{2}{*}{ ASHRAE [86] } \\
\hline & $19-26.5$ & Winter & \\
\hline & \multicolumn{3}{|c|}{ Occupational } \\
\hline & $23-26$ & Summer & CSA [88] \\
\hline & $20-23.5$ & Winter & \\
\hline \multirow[t]{2}{*}{ RH (\%) } & $30-80$ & Summer & \multirow[t]{2}{*}{ Health Canada [82] } \\
\hline & $30-55$ & Winter & \\
\hline
\end{tabular}

$A T$, averaging time; $T V O C$, total volatile organic compounds; $P M$, particulate matter; $R H$, relative humidity. 
IAQ. Some IAQ and occupational safety standards are tabulated in Table 4, adapted from Toprak et al. [77]. In comparison to the common sources of pollutant emissions, release of contaminants to indoor air during storage, experimental and analytical procedures play a major role for laboratory IAQ. The storage areas should be away from sunlight and should be well ventilated with an exclusive exhaust. Temperature should be kept stable. Chemicals should be kept in sealed containers both to reduce the exposure level and to avoid interaction with other chemicals. The same precautions are also valid for chemical wastes. Containers, in which chemical wastes are accumulated, must be resistant to chemical effects, sealed and should be kept in well-ventilated spaces.

In addition to source control, ventilating at rates according to occupant density and potential contaminant sources is the other major management tool for acceptable IAQ. The minimum outdoor airflow rates required per person $\left(R_{\mathrm{p}}\right)$ and per unit area $\left(R_{\mathrm{a}}\right)$ were recommended as $5 \mathrm{~L} / \mathrm{s}$.person and $0.9 \mathrm{~L} / \mathrm{s} \mathrm{m}^{2}$, respectively for both science and university/college laboratories [78]. The $\mathrm{ACH}$ in laboratories was also recommended in the range of 6-12 $\mathrm{ACH}$ [79]. However, it was also stated that the ventilation rates in this range may not be appropriate for all types of laboratories. The hazard level of materials expected to be used in the laboratories and the operation and procedures to be performed should also be considered, then minimum ventilation rates should be determined on a laboratory-by-laboratory basis [80]. In addition, fume hoods as local exhaust ventilation devices should be used for especially potential exposure experiments. Their use helps preventing instantaneous large variations in IAQ. Conducting experiments under fume hoods allows chemicals to be removed without dispersion into the indoor environment. Another important issue about mechanical ventilation systems is that contaminants may accumulate in ventilation ducts creating additional sources of pollution with potential for adverse health effects. Re-entrainment of pollutants emitted from laboratory and fume hood exhausts back into supply air would result in risen exposure in the laboratories and in the other microenvironments in the building spread by the ventilation system. Components of HVAC systems may become fertile grounds for microbial growth, one of the most important sources of risk, resulting in infection of scores of people. Because of these reasons, application of regular care/maintenance and cleaning procedures on the HVAC systems have very important roles for keeping the IAQ at acceptable levels.

\section{REFERENCES}

[1] R.H.M. Godoi, A.F.L. Godoi, S.J. Goncalves, S.L. Paralovo, G.C. Borillo, C.G.G. Barbosa, M.G. Arantes, R.C. Charello, N.A. Rosario, M.T. Grassi, C.I. Yamamoto, S. PotgieterVermaak, G.G. Rotondo, K. De Wael, R. van Grieken, Sci. Total Environ. 463 (2013) 639-646.

[2] J. Madureira, I. Paciencia, O. Fernandes Ede, J. Toxicol. Environ. Health A 75 (22-23) (2012) 1423-1436. 
[3] Y. Tesfaigzi, S.P. Singh, J.E. Foster, J. Kubatko, E.B. Barr, P.M. Fine, J.D. McDonald, F.F. Hahn, J.L. Mauderly, Toxicol. Sci. 65 (1) (2002) 115-125.

[4] K. Donaldson, V. Stone, A. Clouter, L. Renwick, W. MacNee, J. Occup. Environ. Med. 58 (3) (2001) 211-216.

[5] M.D. Keywood, G.P. Ayers, J.L. Gras, R.W. Gillett, D.D. Cohen, Atmos. Environ. 33 (18) (1999) 2907-2913.

[6] E. Abt, H.H. Suh, G. Allen, P. Koutrakis, Environ. Health Perspect. 108 (1) (2000) 35-44.

[7] Y. Ocak, A. Kılıçvuran, A.B. Eren, A. Sofuoglu, S.C. Sofuoglu, Atmos. Environ. 56 (2012) $169-176$.

[8] WHO, Exposure to Arsenic: A Major Public Health Concern, World Health Organization, 2010 .

[9] A.J. Ghio, Y.-C.T. Huang, Inhal. Toxicol. 16 (1) (2004) 53-59.

[10] A.D. Kappos, P. Bruckmann, T. Eikmann, N. Englert, U. Heinrich, P. Höppe, E. Koch, G.H.M. Krause, W.G. Kreyling, K. Rauchfuss, P. Rombout, V. Schulz-Klemp, W.R. Thiel, H.E. Wichmann, Int. J. Hyg. Environ. Heal. 207 (4) (2004) 399-407.

[11] J. Vermylen, A. Nemmar, B. Nemery, M.F. Hoylaerts, JTH 3 (9) (2005) 1955-1961.

[12] B. Brunekreef, S.T. Holgate, The Lancet 360 (9341) (2002) 1233-1242.

[13] A.I. Calvo, C. Alves, A. Castro, V. Pont, A.M. Vicente, R. Fraile, Atmos. Res. 120-121 (0) (2013) $1-28$.

[14] L.Y. Alleman, L. Lamaison, E. Perdrix, A. Robache, J.-C. Galloo, Atmos. Res. 96 (4) (2010) $612-625$.

[15] K.C. Crist, B. Liu, M. Kim, S.R. Deshpande, K. John, Environ. Res. 106 (1) (2008) 62-71.

[16] O. Wada, Jpn. Med. Assoc. J. 47 (8) (2004) 351-358.

[17] U. Satish, M.J. Mendell, K. Shekhar, T. Hotchi, D. Sullivan, S. Streufert, W.J. Fisk, Environ. Health Persp. 120 (2012) 1671-1677.

[18] J.A. Bernstein, N. Alexis, H. Bacchus, I.L. Bernstein, P. Fritz, E. Horner, N. Li, S. Mason, A. Nel, J. Oullette, K. Reijula, T. Reponen, J. Seltzer, A. Smith, S.M. Tarlo, J. Allergy Clin. Immunol. 121 (3) (2008) 585-591.

[19] A. Cattaneo, M. Taronna, D. Consonni, S. Angius, P. Costamagna, D.M. Cavallo, J. Occup. Environ. Hyg. 7 (6) (2010) 342-351.

[20] A.P. Jones, Atmos. Environ. 33 (28) (1999) 4535-4564.

[21] S. Oesch, M. Faller, Corros. Sci. 39 (9) (1997) 1505-1530.

[22] N. Jariyasopit, M.M. Intosh, K. Zimmermann, J. Arey, R. Atkinson, P.H.-Y. Cheong, R.G. Carter, T.-W. Yu, R.H. Dashwood, S.L.M. Simonich, Environ. Sci. Technol. 48 (1) (2014) 412-419.

[23] E.J. Bardana, A. Montanaro (Eds.), Indoor Air Pollution and Health, 1997. New York.

[24] L.M. Neas, D.W. Dockery, J.H. Ware, J.D. Spengler, F.E. Speizer, B.G. Ferris, Am. J. Epidemiol. 134 (2) (1991) 204-219.

[25] Y. Li, T.E. Powers, H.D. Roth, J. Air Waste Manage. 44 (3) (1994) 261-270.

[26] N.R. Frank, M.O. Amdur, J. Worcester, J.L. Whittenberger, J. Appl. Physiol. 17 (2) (1962) $252-258$.

[27] E.N. Schachter, T.J. Witek, G.J. Beck, H.R. Hosein, G. Colice, B.P. Leaderer, W. Cain, Arch. Environ. Health 39 (1) (1984) 34-42.

[28] M.O. Amdur, W.W. Melvin, P. Drinker, The Lancet 2 (1953) 758-759.

[29] S. Rabinovitch, N. Greyson, W. Weiser, V. Hoffstein, Am. Rev. Respir. Dis. 139 (1989) $556-558$.

[30] M. Maroni, B. Seifert, T. Lindvall (Eds.), Indoor Air Quality: A Comprehensive Reference Book, Elseiver, Amsterdam, 1995. 
[31] B.M. Branan, J.T. Butcher, L.R. Olsen, J. Chem. Educ. 84 (12) (1979) 2007.

[32] C.J. Weschler, Indoor Air 10 (4) (2000) 269-288.

[33] R.B. Devlin, J.A. Raub, L.J. Folinsbee, Sci. Med. 4 (1997) 8-17.

[34] S. Parmet, C. Lynm, R.M. Glass, JAMA 290 (14) (2003) 1944.

[35] S.D. Pillai, S.C. Ricke, Can. J. Microbiol. 48 (8) (2002) 681-696.

[36] N. Kalogerakis, D. Paschali, V. Lekaditis, A. Pantidou, K. Eleftheriadis, M. Lazaridis, J. Aerosol Sci. 36 (5-6) (2005) 751-761.

[37] T. Godish, Indoor Environmental Quality, 2000. Boca Raton, FL.

[38] IEH, Assessment on Indoor Air Quality in the Home, Institute for Environment and Health, Leicester, UK, 1996.

[39] WHO, Indoor air quality: organic pollutants, Environ. Technol. Lett. 10 (9) (1989) 855-858.

[40] J.E. Cometto-Muñiz, W.S. Cain, M.H. Abraham, Indoor Air 14 (s8) (2004) 108-117.

[41] A.E. Pouli, D.G. Hatzinikolaou, C. Piperi, A. Stavridou, M.C. Psallidopoulos, J.C. Stavrides, Free Radic. Bio. Med. 34 (3) (2003) 345-355.

[42] P. Wolkoff, C. Wilkins, P. Clausen, G. Nielsen, Indoor Air 16 (1) (2006) 7-19.

[43] C.J. Weschler, W.W. Nazaroff, Atmos. Environ. 42 (40) (2008) 9018-9040.

[44] A. Gómez-Hens, M.P. Aguilar-Caballos, Trac-Trend Anal. Chem. 22 (11) (2003) 847-857.

[45] ATSDR, Toxicological profile for di(2-ethylhexyl)phthalate, Department of Health and Human Services, Public Health Service, Atlanta, GA, 2002.

[46] J.A. Hoppin, R. Ulmer, S.J. London, Environ. Health Persp. 112 (5) (2004) 571.

[47] R.W. Stahlhut, E. van Wijngaarden, T.D. Dye, S. Cook, S.H. Swan, Environ. Health Persp. 115 (6) (2007) 876-882.

[48] S.H. Swan, Environ. Res. 108 (2) (2008) 177-184.

[49] K.C. Jones, P. de Voogt, Environ. Pollut. 100 (1-3) (1999) 209-221.

[50] Q. Qing Li, A. Loganath, Y. Seng Chong, J. Tan, J. Philip Obbard, J. Toxicol. Environ. Health A 69 (21) (2006) 1987-2005.

[51] H.W. Vallack, D.J. Bakker, I. Brandt, E. Broström-Lundén, A. Brouwer, K.R. Bull, C. Gough, R. Guardans, I. Holoubek, B. Jansson, R. Koch, J. Kuylenstierna, A. Lecloux, D. Mackay, P. McCutcheon, P. Mocarelli, R.D.F. Taalman, Environ. Toxicol. Phar. 6 (3) (1998) 143-175.

[52] USEPA, Moisture Control Guidance for Building Design, Construction and Maintenance, U.S. Environmental Protection Agency, 2013. EPA 402-F-13053.

[53] L. Lan, Z. Lian, L. Pan, Appl. Ergon. 42 (1) (2010) 29-36.

[54] ISO7730, Moderate thermal environments e determination of the PMV and PPD indices and specification of the conditions for thermal comfort, International organization for standardization, Geneva, 1993.

[55] O. Seppänen, W.J. Fisk, D. Faulkner, in: Proceedings of the Healthy Buildings 2003 Conference, Singapore 3, 2003, pp. 394-399.

[56] L. Reinikainen, J. Jaakkola, Indoor Air 13 (4) (2003) 344-352.

[57] N. Pellerin, V. Candas, Indoor Air 14 (2) (2004) 129-136.

[58] A. Cavatorta, M. Falzoi, A. Romanelli, F. Cigala, M. Ricco, G. Bruschi, I. Franchini, A. Borghetti, J. Hypertens. 5 (5) (1987) S463-S466.

[59] M.A. Crook, F.J. Langdon, J. Sound Vib. 34 (2) (1974) 221-232.

[60] T. Lang, C. Fouriaud, M.-C. Jacquinet-Salord, Int. Arch. Occup. Environ. Health 63 (6) (1992) 369-372.

[61] S. Melamed, J. Luz, M. Green, Isr. J. Med. Sci. 28 (8-9) (1991) 629-635.

[62] Y.M. Zhao, S.Z. Zhang, S. Selvin, R.C. Spear, Brit. J. Ind. Med. 48 (3) (1991) 179-184.

[63] L. Huang, Y. Zhu, Q. Ouyang, B. Cao, Build. Environ. 49 (0) (2012) 304-309. 
[64] USEPA, Building Air Quality, A Guide for Building Owners and Facility Managers, EPA, Washington, DC, 1987.

[65] T. Hitchcock, W.E. Murray, R.M. Patterson, R.J. Rockwell, Am. Ind. Hyg. Assoc. J. (1997) 490-579.

[66] ASHRAE, Standard 90.1. Energy Standard for Buildings Except Low-rise Residential Buildings, American Society of Heating, Refrigerating and Air-Conditioning Engineers, Atlanta, GA, 2010.

[67] M.J. Griffin, Occup. Environ. Med. 61 (5) (2004) 387-397.

[68] M. Pope, M. Magnusson, R. LundstrÖM, C. Hulshof, J. Verbeek, M. Bovenzi, J. Sound Vib. 253 (1) (2002) 131-167.

[69] M. Brancher, H. de Melo Lisboaa, Chem. Eng. Trans. 40 (2014) 139-144.

[70] W.S. Cain, M.R. Garcia-Medina, in: Presented at the Annual Meeting of the Air Pollution Control Association, Montral, Quebec, 1980.

[71] E.A. Emmett, Brit. J. Ind. Med. 33 (3) (1976) 196-198.

[72] K. Rumchev, V. Broeck, J. Spickett, Environ. Health 3 (2003) 11-19.

[73] A. Valavanidis, M. Vatista, Indoor Built Environ. 15 (6) (2006) 595-605.

[74] Y.H. Yau, B.T. Chew, A.Z.A. Saifullah, Int. J. Sust. Built Environ. 1 (1) (2012) 110-124.

[75] J. Park, L. Lee, H. Byun, S. Ham, I. Lee, J. Park, K. Rhie, Y. Lee, J. Yeom, P. Tsai, C. Yoon, J. Clean. Prod. 66 (0) (2014) 10-18.

[76] T. Ugranli, M. Toprak, G. Gursoy, A.H. Cimrin, S.C. Sofuoglu, Atmos. Pollut. Res. 6 (1) (2015) $147-153$.

[77] M. Toprak, G. Gursoy, Y. Demiral, A.H. Cimrin, S. Sofuoglu, Hava Kirliligi Arastirmalari Dergisi 2 (2013) 87-95 (in Turkish).

[78] ASHRAE, ASHRAE Handbook - 2007 HVAC Applications (Chapter 14), Laboratories, American Society of Heating, Refrigerating and Air-Conditioning Engineers, Atlanta GA, 2007.

[79] ASHRAE, Standard 62.1: Ventilation for Acceptable Indoor Air Quality, American Society of Heating, Refrigerating and Air Conditioning Engineers, Inc, Atlanta, GA, 2007.

[80] ASHRAE, ASHRAE Handbook - 2011 HVAC Applications (Chapter 16), Laboratories American Society of Heating, Refrigerating and Air Conditioning Engineers, Inc, Atlanta, GA, 2011.

[81] USEPA, National Ambient Air Quality Standards, U.S. Environmental Protection Agency, 2000.

[82] Health Canada, Exposure Guidelines for Residential Indoor Air Quality: A Report of the Federal-provincial Advisory Committee on Environmental and Occupational Health, 1995. Ottawa, 29 pages.

[83] WHO, Air Quality Guidelines for Europe, European Series No. 91, second ed., World Health Organization Regional Publications, Copenhagen, 2000, 288 pages.

[84] MAK, Maximum Concentrations at the Workplace and Biological Tolerance Values for Working Materials, 2000.

[85] NIOSH, Carbon dioxide, National Institute for Occupational Safety and Health, 1992.

[86] ASHRAE, Standard 55-2004: Thermal Environmental Conditions for Human Occupancy, American Society of Heating, Refrigerating and Air-Conditioning Engineers,, Atlanta, 2004, 7 pages.

[87] B. Seifert, N. Englert, H. Sagunski, J. Witten, in: Indoor Air'99, August 8-13, Edinburg, Scotland, 1999, pp. 499-504.

[88] CSA, Canadian Standards Z412-00, R2005 - Guideline on Office Ergonomics, Canadian Standards Association, 2005. 